\title{
Analysis of results of biomass forest inventory in northeastern Amazon for development of REDD+ carbon project
}

\author{
LEONEL N.C. MELLO ${ }^{1}$, MARCIO H.R. SALES ${ }^{2}$ and LUIZ P. ROSA ${ }^{3}$ \\ ${ }^{1}$ Universidade Federal do Rio de Janeiro, PPE - Centro de Tecnologia, Bloco C, Sala 211, Cidade Universitária, \\ Ilha do Fundão, Av. Horácio Macedo, 2030, C.P. 68565, 21941-450, Rio de Janeiro, RJ, Brasil \\ ${ }^{2}$ Wageningen University, Laboratory of Geo-information Science and Remote \\ Sensing, Droevendaalsesteeg 4, 6708 PB Wageningen, Netherlands \\ ${ }^{3}$ International Virtual Institute on Global Change/IVIG, COPPE, UFRJ, Ilha do Fundão, Av. Pedro Calmon, \\ 2-64, Galeão, Centro de Tecnologia, Bloco 1, Sala 129, 21945-970 Rio de Janeiro, RJ, Brasil
}

Manuscript received on November 27, 2014; accepted for publication on June 22, 2015

\begin{abstract}
In Brazil, a significant reduction in deforestation rates occurred during the last decade. In spite of that fact, the average annual rates are still too high, approximately $400.000 \mathrm{ha} / \mathrm{year}$ (INPE/Prodes). The projects of emissions reduction through avoided deforestation (REED+) are an important tool to reduce deforestation rates in Brazil. Understanding the amazon forest structure, in terms of biomass stock is key to design avoided deforestation strategies. In this work, we analyze data results from aboveground biomass of 1,019.346,27 hectares in the state of Pará. It was collected data from 16,722 trees in 83 random independent plots. It was tested 4 allometric equations, for DBH $>10 \mathrm{~cm}$ : Brown et al. (1989), Brown and Lugo (1999), Chambers et al. (2000), Higuchi et al. (1998). It revealed that the biggest carbon stock of above ground biomass is stocked on the interval at DBH between $30 \mathrm{~cm}$ and $80 \mathrm{~cm}$. This biomass compartment stocks $75.70 \%$ of total biomass in Higuchi et al. (1998) equation, $75.56 \%$ of total biomass in Brown et al. (1989) equation, $78.83 \%$ of total biomass in Chambers et al. (2000) equation, and 73.22\% in Brown and Lugo (1999) equation.
\end{abstract}

Key words: deforestation in Amazon, REDD+ Projects, Climate change, Carbon forest.

\section{INTRODUCTION}

The needed role of REDD in overall efforts to contain global warming, together with the social and environmental co-benefits of using this mechanism to maintain Amazon forest, make further improvement a high priority (Fearnside et al. 2013).

Correspondence to: Leonel Neves do Canto e Mello

E-mail: leonel.mello13@gmail.com
The high costs for implementation of REDD projects and the uncertainties surrounding the supply and demand of REDD + credits produce a number of potential risks, including market flooding, price volatility, and the timing of unit issuance. These are constrains that prevents more projects to be developed. Moreover, direct risks associated to small revenue related to generating carbon credits, which are relatively small, and the high transaction costs (Tennigkeit et al. 2013) represent a barrier to 
more investment. For these reasons, reducing costs of project development and implementation can be a stimulus to attract more investment and therefore more projects on the ground.

Amongst the higher costs is the forest biomass inventory. Especially for large-scale projects. All reviews conclude that comprehensive, fieldderived carbon measures are labor intensive, time consuming, expensive, often destructive, and therefore generally prohibitive over extensive areas (Gibbs et al. 2007a). The aim of this work was to analyze gathered information from a biomass field inventory, and provide data to enable project developers to improve efficiency and effectiveness of the field and deskwork.

Brazil is home to the world's largest tract of intact rainforest - an area roughly the same size as the EU. It is estimated that the Amazon rainforest generates up to half of the rainfall, which agriculture and hydropower plants in southeastern Brazil and in the rest of South America depend on. It helps to regulate the global climate, sequestering millions of tons of carbon every year. And all this while safeguarding a fifth of the world's freshwater and perhaps a third of its biodiversity (Nassar et al. 2010).

Nevertheless, Brazil is also an agricultural power. It is the leader producer and exporter of coffee, sugar, ethanol, orange juice, soybean and meat. Brazil's agricultural sector presented records of exports in 2013. The country has accumulated an $216,45 \%$ increase of agricultural exports in the last 15 years. The agricultural sector is sailing through the current economic crisis largely unscathed. The sector was the only one to have a positive performance in the 2015 gross national product (IBGE 2015).

But this agricultural economic growth has a high environmental cost. Looking at the last decade, with its stubbornly high deforestation levels, a strong argument can be made that the trend in the Amazon is towards more and higher levels of deforestation, driven mainly by agribusiness, broadly defined.

The states of Mato Grosso and Pará have been the leader states on deforestation rates in the last decade (INPE). Both states are located in an agriculture deforestation frontier called "Arc of Deforestation" referring to the crescent-shaped area along the eastern and southern edges of the Amazon forest (Hayashi et al. 2010). In these regions, wood logging activities, ranching and soybean plantations, turn out to be a perfect ingredient combination for astonishing deforestation rates.

In that sense, the Amazon turns out to be most challenge sustainability region in the world. The region is home of 30 million people and supplies natural resources to the whole world. The benefits are not restricted to products, but also ecosystem services, such as climate regulation and biodiversity conservation (Gardner et al. 2013).

According to INPE (National Institute of Space Research), the rate of deforestation in the last 9 years in the Amazon region reached an average of $12,000 \mathrm{~km}^{2}$ per year. This rate has decreased, drastically, in recent years (in 2012 it was $4,571 \mathrm{~km}^{2}$, the lowest since start monitoring), but it still is an unacceptable rate for a country with a voluntary target to reduce its emissions $36 \%$ to $38 \%$ in relation to 2005 .

In 2013, the rates increased again after 10 years of reduction. This deforestation rates were reduced through command and control instruments, but these instruments are not cost-efficient when compared to market mechanisms (Perman 2003). Therefore, the development of REDD+ projects and programs are an important alternative to reduce deforestation rates in long-term basis (Berenguer et al. 2014). In 2007, at its 13th Conference of the Parties, the UN Framework Convention on Climate Change (UNFCCC) recognized forest degradation as an important contributor to global carbon emissions by incorporating it into the Reducing Emissions from Deforestation and Forest 
Degradation (REDD+) mechanism (Dutschke et al. 2008). The future of REDD and related climate policies need not be constrained by the technical challenges of estimating tropical forest carbon stocks (Gibbs et al. 2007b).

In that sense, large-scale forest inventories in the Amazon are crucial for delivering data to REDD + project developers. Mainly, on the amazon region deforestation frontier, where cattle raising, first, and agriculture second, are encroaching the forest.

Data on biomass and carbon storage in Amazonian forests are limited. The carbon stock in these regions have been widely studied, but few are large scale studies focused on REDD projects. Clearly, there is a need for additional studies of Amazon forest biomass (Laurance et al. 1999).

The carbon stock in these regions have been widely studied, but few are large scale studies focused on REDD+ projects. Therefore, there is a gap of studies of ground based biomass forest structure oriented to development of emission reduction projects.

This work presents the results of a forest inventory developed in an area of 1,019.346,27 ha in the state of Pará. For that, 83 random plots of one hectare were established and the above ground biomass content (including palms and lianas) was estimated through a biomass inventory (Lat 51 23 '30"W - 51'3'0"W and Lon $1^{\circ} 40^{\prime} 45^{\prime \prime} \mathrm{S}-2^{\circ} 32^{\prime} 0$ "'S). Biomass content of three types of forest classes were analyzed: i) forest (dense forests); ii) forest with signs of degradation (forest in degradation); iii) regeneration (forest in regeneration). The third land cover type contains all deforested areas that presented regeneration. The other classes were not considered in the study because corresponds to less than $1 \%$ of the total area.

Ecosystem Services LLC financed the project, and Setambiental Consultancy Services Ltda executed the inventory.
The use of allometric equations outside the regions for which they have been produced is a major source of uncertainty (Bruce et al. 1998). Allometric equations are based on relating measured tree biomass to factors like tree diameter, or diameter and height, averaged over a large number of individuals (of varying characteristics like wood density). Baker et al. (2004) analyzed data from several sites in Amazonia and found that mean stand-level wood density is greater in the central and eastern Amazon than in northern or southwest Amazonia. These authors have suggested applying a simple multiplicative density correction factor to the allometry equation to account for these differences (Baker et al. 2004). However, tree height as well as wood density vary among our sites, and may confound the use of this density correction factor.

This work tested four allometric equations: Brown et al. (1989), Brown and Lugo (1999), Chambers et al. (2000), Higuchi et al. (1998) for trees with diameter at breast weight above $10 \mathrm{~cm}(10-200 \mathrm{~cm})$. Moreover, the biomass per hectare of small trees $(3<\mathrm{DBH}<10 \mathrm{~cm})$, seedlings $(\mathrm{DBH}<3 \mathrm{~cm})$ and litter, was also estimated in an area of 1,019.346,27 hectares in same area.

The biomass content per hectare estimated in this work is accordingly to other works in the Amazon region. Costa et al. (2012) used Higuchi et al. (1998) equation in primary forest areas located at Pacajá municipality, Paraupebas municipality and Nova Ipixuna municipality, Pará. It is important to compare this work with Costa et al. (2012) because Costa stratified his study area in 4 similar strata to the ones of this work.

In another study, Vieira et al. (2004) used Chambers et al. (2000) equation, because this equation had already been tested in areas out of central Amazonia, and it presented good results. However, the equation of Chambers et al. (2000) uses the ratio between tree density and average density of the plot ( $\rho \mathrm{i} / \mathrm{\rho m})$, and it recommends a 
$\rho \mathrm{i} / \rho \mathrm{m}=-0,370$. Baker et al. (2004) suggested a correction factor for each area. The error was identified by Vieira et al. (2004), who found a reduction of $18 \%$ in the estimated biomass at Rio Branco, State of Acre.

Chambers et al. (2000) found that an allometric equation based on trees harvested near Manaus gave about the same forest-wide biomass predictions as an allometric equation based on trees harvested in the state of Pará (Araújo et al. 1999). Vieira et al. (2003) showed that the Chambers et al. (2000) equation overestimates aboveground biomass in the southwestern Amazon by 22\% when both tree height and wood density are taken into account.

Baker et al. (2004) analyzed data from several sites in Amazonia and found that mean stand-level wood density is greater in the central and eastern Amazon than in northern or southwest Amazonia. These authors have suggested applying a simple multiplicative density correction factor to the allometry equation to account for these differences (Baker et al. 2004).

While acknowledging the inherent uncertainties, we have chosen to test data using the Chambers et al. (2000) for our forests sites to accept the $22 \%$ correction suggested by Vieira et al. (2003) for the Rio Branco site, until future tests of the allometry equations are available for these sites. Nogueira (2008) also used Chambers et al. (2000) equation for trees DBH $>10 \mathrm{~cm}$. Brown et al. (1989) equation was also used because it has been widely accepted by many authors, and has been recommended for forested inventories.

The major aim of this work is to provide, to REDD+ project developers and REDD+ methodology developers, data that may be useful to plan and design carbon forest inventories. In addition, the logistics are complex, specialized labor is rare, local and experienced workers are few. Therefore, the results presented by this study provide project developers with valuable data, to reduce costs and make project development more efficient and effective.

\section{MATERIALS AND METHODS}

STUDY AREA AND SAMPLING DESIGN

Total Project area is $1,019,346.27$ hectares, and was stratified into 3 forest typology: Dense forest $(830,631.10 \mathrm{ha})$, degraded forest $(75,386.04$ ha), regeneration forest $(23,243.87 \mathrm{ha})$. It was established 83 random plots of one ha to obtain a sample error of $12 \%$. To this end, optimal plot allocation was 75 plots for dense forest, 5 plots for degraded forest and 3 plots for regeneration forest.

Data was collected from trees of 3 diameter classes: tress $(\mathrm{DBH}>10 \mathrm{~cm})$; small trees $(3 \mathrm{~cm}<$ $\mathrm{DBH}<9,9 \mathrm{~cm}$ ); seedlings ( $\mathrm{DBH}<3 \mathrm{~cm}$ ) and litter. The plots have a square shape and it was divided into 4 sub-plots of 0,25 ha. All trees with diameter at breast high above $10 \mathrm{~cm}$ was measured in 83 hectare plots (16.722 trees were measured).

The sub-plots were established to collected data from small trees $(3 \mathrm{~cm}<\mathrm{DBH}<9 \mathrm{~cm})$. Every small tree was counted in 2 sub-plots $(0.5 \mathrm{ha})$ for each of the 83 plots. Then, 62 small trees were fresh weighted in the field, and then dry weighted in the lab. Total biomass of this compartment was achieved through cross-multiplication.

Micro plots of $1 \mathrm{~m}^{2}$ were stablished in order to estimate biomass of seedlings $(\mathrm{DBH}<3 \mathrm{~cm})$ and litter. Samples of $200 \mathrm{mg}$ were fresh weighted in the field and taken to the lab for dry weight. The ratio fresh weight/dry weight of the $200 \mathrm{~g}$ samples was multiplied by total fresh weight of the samples from the micro plots.

\section{ALLOMETRIC EQUATIONS}

Preference was given to equations that used exclusively $\mathrm{DBH}$, as measurement of this variable had more accuracy, than tree high or tree density. Even though tree high was estimated, it was not used, as it could result in much higher uncertainty to biomass estimates. Wood density was not measured, due to the high species diversity of the 
study region, which would make it impossible to measure, besides increasing uncertainties. According to Chave et al. (2005), wood density is a taxonomic characteristic, and it depends on the growth strategy of the tree species (Nogueira 2008). Thus, uncertainty in wood density arises as variability resulting from natural disturbance, light availability, humidity and climate. Wood density also varies at a rate inversely proportional to soil fertility. For the reasons mentioned above wood density was not measured. For the only equation that required wood density, the factor $-0,37$ was used, based on Chambers et al. (2000), used by Vieira et al. (2004).

TABLE I

\begin{tabular}{|c|c|c|}
\hline DBH class & Equations & Reference \\
\hline No specific class & $\mathrm{DB}=38,4908-11,7883(\mathrm{DBH})+1,1926 *(\mathrm{DBH})^{2}$ & Brown et al. (1989) \\
\hline $\mathrm{DAP} \geq 10 \mathrm{~cm}$ & $\mathrm{DB}=\operatorname{Exp}\left[-2.289+2.649 * \ln (\mathrm{DBH})-0.021 *\left((\ln (\mathrm{DAP}))^{2}\right]\right.$ & Brown et al. (1989) \\
\hline $\mathrm{DAP} \geq 10 \mathrm{~cm}$ & $\begin{array}{l}\ln (\mathrm{DB})=\left(\operatorname{den}_{\mathrm{l}} / \mathrm{den}_{\mathrm{m}}\right)+0,333 \ln (\mathrm{DBH})+0,933[\ln (\mathrm{DBH})]^{2}-0,122[(\mathrm{DBH})]^{3} \\
\text { den }_{\mathrm{I}=} \text { Average tree density } \\
\text { den }_{\mathrm{m}=} \text { Average density of sampled trees } \\
\left(\text { den }_{\mathrm{l}} / \mathrm{den}_{\mathrm{m}}\right)=-0,37 \text { assuming the same density of Chambers et al. }(2000), \\
\text { used by Vieira et al. }(2004)\end{array}$ & Chambers et al. (2000) \\
\hline $\mathrm{DAP}>20 \mathrm{~cm}$ & $\mathrm{DB}=\exp (-0,51+2,17 \times \operatorname{Ln}(\mathrm{DBH})) \times 0,57)$ & Higuchi et al. (1998) \\
\hline
\end{tabular}

\section{STATISTICAL ANALYSIS (BOOTSTRAPPING)}

We performed the following analysis: comparison of allometric equations, importance of each biomass component to total biomass. The analysis were made using the following bootstrapping procedure: for each sample, total bole biomass (dry weight, in ton/ha) was estimated for trees with $10 \mathrm{~cm}>$ DBH $>200$ cmusing each allometric equation described in each allometric equation tested in the present research. To test for significant differences between total biomass due to the choice of the allometric equation, we first performed a 1000 bootstrap of our samples, where for every bootstrap sample the total biomass for each diameter class was calculated for each equation. Then, bootstrap confidence intervals were used to compare total biomass between equations, for each diameter class, to identify which classes are most influenced by the choice of the allometric equation. We also included the biomass of litter in our bootstrap procedure, to evaluate the significance of this compartment for total biomass per hectare. All analysis were performed in R.
ANALYSIS OF THE TIME TAKEN TO MEASURE THE BIOMASS IN EACH COMPARTMENT

The activities to develop the inventory were divided in five phases: Planning, field data collection, data processing, data analyses and report preparation. In order to estimate the time taken to measure the biomass in each compartment, It was registered the number of hours spend to estimate biomass on each phase. A table was developed presenting total number of hours spent for estimation of biomass on each compartment and its respective average biomass.

\section{RESULTS AND DISCUSSION}

The large number of trees measured in this work (16.722) provides a richer database than most inventories that have been used in allometric studies, for which few or even no data exist for large trees in the Amazon region. The range of the average of total above ground biomass (AGB) per hectare found in this study $-196,974$ tons/ha (using Brown's 1989 equation) to 255,588 tons/ha (using Higuchi 1998 equation) is lower than the average 
for total AGB per hectare reported by Araujo et al. (1999), for forest with degradation and intact forests (225,00 tons/ha and 486,00 ton/ha, respectively). The lower averages in this work can be attributed to the fact that the analysis included all forest typologies (forest in degradation, dense forest and forest in regeneration), differently from the study developed by Fearnside, which the average of total AGB was exclusively for either dense forest or forest with degradation.

On the other hand, this work results' is accordingly to the conclusions presented by Vieira et al. (2004). In their study about forest structure and carbon dynamics in the Amazon tropical rain forest, using Chambers et al (2000) equation, they found that $37.5 \%, 24.4 \%$, and $18.9 \%$ of the total AGB was in the medium tree size class for Manaus, Rio Branco, and Santarém sites, respectively. In this work, the biomass stock in the medium tree size class $(30-50 \mathrm{~cm})$ is in average $35,67 \%$ of total
AGB. The average of total dry AGB estimated in the year of forest plots establishment was greatest (360 Mg ha-1) in Manaus, smallest (190 Mg ha-1) in Rio Branco, and $281 \mathrm{Mg}$ ha-1 in Santarém. The higher biomass per hectare found in the Manaus forests compared to this work, is probably because we included degraded forests and forest in regeneration in our estimations. However, these results also corroborate to the thesis that the AGB is highly dependent to forest region and location.

\section{COMPARING THE RESULTS OF ALLOMETRIC EQUATIONS}

From diameter at breast high (DBH) class $100 \mathrm{~cm}$ to DBH class $200 \mathrm{~cm}$, all equations converge to the same average total biomass per hectare (Figure 1). Bars represent the $95 \%$ confidence interval. The Table I shows that the diameter class interval with the greatest biomass stock ranges from 30 to $80 \mathrm{~cm}$. With Higuchi equation presenting the highest average.

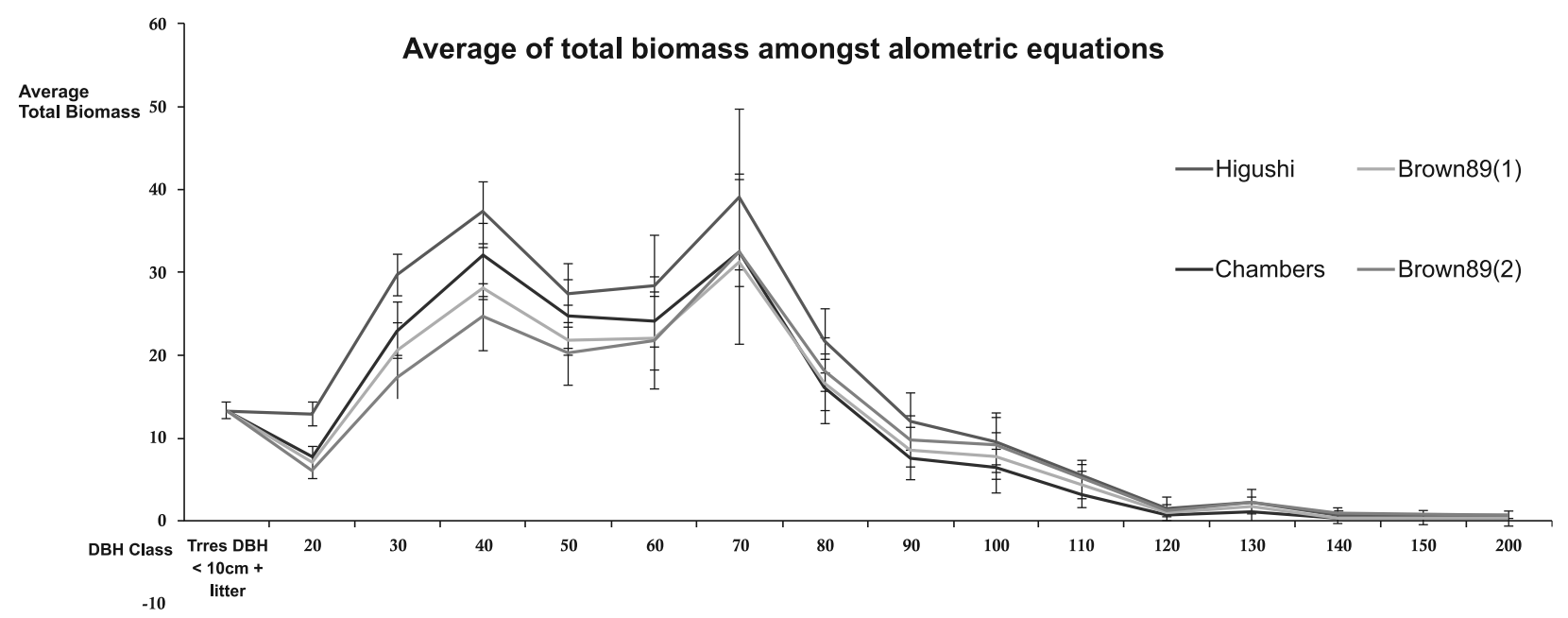

Figure 1

The greatest biomass volume is stocked on the DBH class $70 \mathrm{~cm}$ in all equations tested - Higuchi et al. (1998): 39,085 ton/ ha; Chambers et al. (2000): 32,421 ton/ha; Brown et al. 1989: 31,255 ton/ha; Brown and Lugo 1999: 32,282 ton/ha. Moreover, there is no statistic difference amongst the equations for that diameter class. The Table II below presents the statics difference amongst the diameter classes studied.

The only DBH classes with statistically significant difference is $10-20 \mathrm{~cm}$ and $20-30 \mathrm{~cm}$, difference being between Brown's (1989) equation 
TABLE II

\begin{tabular}{cccc}
\hline DBH Class (cm) & & DBH Class (cm) & \\
\hline $10-20$ & Brown (1989) - Higuchi et al. (1998) & $90-100$ & $* * * *$ \\
\hline $20-30$ & Brown and Lugo (1999) - Higuchi et al. (1998) & $100-110$ & $* * * *$ \\
\hline $30-40$ & $* * * *$ & $110-120$ & $* * * *$ \\
\hline $40-50$ & $* * * *$ & $120-130$ & $* * * *$ \\
\hline $50-60$ & $* * * *$ & $130-140$ & $* * * *$ \\
\hline $60-70$ & $* * * *$ & $140-150$ & $* * * *$ \\
\hline $70-80$ & $* * * *$ & $150-200$ & $* * * *$ \\
\hline $80-90$ & $* * * *$ & & \\
\hline
\end{tabular}

**** No significant difference amongst 4 equations.

and Higuchi et al. (1998) equation. For all other classes there is no statistical significant difference amongst the equations.

The results of AGB of the present work are also lower than the range of biomass volume found in literature from another study for the Amazon rain forest. The average of dry AGB in the Amazon was estimated to be between 276 and $374 \mathrm{Mg}$.ha-1 by Brown and Lugo (1999); or $327 \mathrm{Mg}$.ha-1 by Fearnside (1994).

Gerwing et al. (2002) studied the implications of forest degradation by comparing the impacts of varying intensities of logging and fire on forest structure and composition. Field inventories in forests whose impacts ranged from none to logged and heavily burned were conducted in $14,10 \mathrm{~m} \mathrm{X}$ $500 \mathrm{~m}$ plots located on 10 properties in the region of Paragominas, Pará, Brazil. In the study developed by Jeffrey, live aboveground biomass of intact forest was estimated at 309 ton ha-1.

In a study developed by Laurance et al. (1999), dry AGB of living trees including palms was estimated in 65, 1 ha plots spanning a $1000 \mathrm{~km}^{2}$ landscape in central Amazonia. Biomass values were derived by measuring the $\mathrm{DBH}$ of all $10 \mathrm{~cm}$ trees in each plot, then using an allometric equation and correction factor for small trees to estimate total tree biomass. Biomass estimates varied more than two-fold, from 231 to 492 metric tons ha, with a mean of $356 \pm 47$ tons ha.

\section{BIOMASS POOLS}

While biomass stocked in the class $30-80 \mathrm{~cm}$ represent in average $75.83 \%$ of total biomass per hectare, the biomass stocked in the small trees + seedlings + litter pool contain in average $6.74 \%$ of total biomass (Table III).

The percentage of biomass stocked in the small trees and litter is accordingly to the results found by Cardenas (1988) cited by Nogueira (2008). In his study he found that for dense forest in Pará, the biomass stocked in the DBH trees $<10 \mathrm{~cm}$, is $3,0 \%$ $-4,6 \%$, and the biomass stocked in litter is 3,5\% - 6\%. And total biomass in dense forest in Pará is 186,1 - 297,4 ton/ha.

TABLE III

\begin{tabular}{|c|c|c|c|c|c|}
\hline & $\begin{array}{c}\text { Total } \\
\text { biomass } \\
\text { (ton/ha) }\end{array}$ & $\begin{array}{l}\text { Total biomass class } \\
30-80 \mathrm{~cm} \text { (ton/ha) }\end{array}$ & $\begin{array}{c}\text { \% of biomass } \\
\text { stocked at class } \\
30-80 \mathrm{~cm}\end{array}$ & $\begin{array}{c}\text { Total Biomass } \\
\text { stocked in small } \\
\text { trees+seedlings+litter }\end{array}$ & $\begin{array}{c}\% \text { of biomass } \\
\text { stocked in small } \\
\text { trees+seedlings+litter }\end{array}$ \\
\hline Higuchi & 255.58 & 183.34 & 71.74 & 13.38 & 5.24 \\
\hline Brown 89 & 199.23 & 140.43 & 70.49 & 13.38 & 6.72 \\
\hline $\begin{array}{l}\text { Brown and } \\
\text { Lugo } 99\end{array}$ & 196.97 & 134.43 & 68.25 & 13.38 & 6.80 \\
\hline Chambers & 206.57 & 152.29 & 73.72 & 13.38 & 6.48 \\
\hline
\end{tabular}


In the study developed by Euler (2008), he affirms that the Jeffrey Chamber's and Higuchi's equations tend to overestimate the biomass of small Biomass stock pools, while it underestimate the biomass of bigger trees.

On the other hand, previously published mixed-species biomass regression models, based on primary and secondary forest trees of the Amazon, were also cross-validated against the trees of a study. Two of these models, based on primary forest plots and using only $\mathrm{DBH}$ as an input, biomass differed by $10 \pm 60 \%$ for central Amazonian secondary forest trees in the size range $5 \pm 25 \mathrm{~cm}$. The overestimate was greatest for the larger trees.

According to a large-scale inventories study developed by Brown and Lugo (1999), the AGB in tree of diameter $10 \mathrm{~cm}$ or larger ranged from $175-$ 397 ton/ha. Most of the biomass estimates (78\%) for these inventories were within the range of 240 to 340 ton/ha. Moreover, they do not included estimates of biomass of other living, aboveground components because they represent a small fraction of the total biomass. For example, the contribution of understory shrubs, vines and herbaceous plants to AGB can be variable but generally very small, about $3 \%$ or less (Levine 1991), although it is likely to be a larger proportion in disturbed forests. Therefore, the results of range for total above ground biomass presented in the study by Brown et al. (1989) is within the range of total above ground biomass presented by this work. On the other hand, the lower percentage of biomass contribution of understory $(3 \%)$ presented by Brown and Lugo (1999), than this work $(5,24-6,8 \%)$, can be attributed to the fact that our forest sites had large areas of disturbed forests.

\section{ANALYSIS OF THE SPENT TIME TO MEASURE THE BIOMASS} IN EACH BIOMASS POOL

The Table IV presents the number of days spent per inventory activity. The Table $\mathrm{V}$ presents the number of working hours per activity and per class of DBH

The time taken to measure the biomass of the lower biomass compartments (tree $<10 \mathrm{~cm}+$ litter) was 284,83 hours, while the time spent to measure the biomass of trees $>10 \mathrm{~cm}$ was 347.17 hours. Therefore, from a cost standpoint, assuming that the costs per unit of time are the same in all phases, it is not efficient to invest $45 \%$ of the time, measuring, approximately, $6.3 \%$ of the total AGB. Moreover, this reduced volume biomass content in the lower forest compartments; represent an impact on the carbon credit generation.

TABLE IV

Number of days spent for development of the inventory.

\begin{tabular}{lcccccc}
\hline Phase & Planning & Field data collection & Data processing & Data analysis & Report preparation & Total \\
\hline Total days & 7 days & 27 days & 20 days & 10 days & 15 days & 79 days \\
\hline
\end{tabular}

TABLE V

Number of hours spent per activity per class.

\begin{tabular}{|c|c|c|c|c|c|c|}
\hline Phase & Planning & $\begin{array}{l}\text { Field data } \\
\text { collection }\end{array}$ & Data processing & Data analysis & $\begin{array}{c}\text { Report } \\
\text { preparation }\end{array}$ & Total \\
\hline Class $>10 \mathrm{~cm}$ & 4.5hours/day & 4.5hours/day & 4.5hours/day & 4.16hours/day & 4.16hours/day & 347.17hours \\
\hline $\begin{array}{l}\text { Small trees } \\
3>\mathrm{DBH}>10 \mathrm{~cm}\end{array}$ & 1.5hours/day & 1.5 hours/day & 1.16hours/day & 1.66hours/day & 1.5 hours/day & 113.5hours \\
\hline $\begin{array}{l}\text { Seedlings } \\
\mathrm{DBH}<3 \mathrm{~cm}\end{array}$ & 1hours/day & 1hours/day & 1.16hours/day & 1.16hours/day & 1.16hours/day & 86.50hours \\
\hline Litter & 1hours/day & 1hours/day & 1.16hours/day & 1hours/day & 1.16hours/day & 84.83hours \\
\hline
\end{tabular}




\section{CONCLUSION}

Because of the sample size and number of plots, the results presented in this work provide a valuable and reliable source of data. As explained in Brown and Lugo (1999) and Brown et al. (1989), direct biomass of few small plots usually yield higher biomass estimates probably because plots were not randomly selected, were not sampled from the population of interest and sample size was small (both number and plot size).

In spite of the fact, that there are great uncertainties and great variety of results for biomass content in the amazon forests, this work demonstrated that for the area of this study, there is not much difference amongst the allometric equation tested. Great part of variation is more due to the forest type and level of degradation than due to allometric equations.

There is a need to keep improving the understanding of how non-trees components should be incorporated in terrestrial carbon models of land use change. Because there is the risk of introducing more errors into the analyses than gaining by their estimation.

On the other hand, estimated costs for development of REDD+ projects in Brazil, from feasibility studies to the carbon credit issuance, ranges from USD 250 to 500 thousand. This cost depends on the region and availability of data. Carbon inventories is amongst the most expensive activities, especially on the amazon region, where logistics are difficult and is highly dependent on local knowledge. For that reason, cost control of carbon forest inventories is very important to make REDD+ projects feasible.

According to results presented for large scale forest carbon projects in the region of this study, it would be important to consider whether to measure trees below $10 \mathrm{~cm}$ of $\mathrm{DBH}$. This because the biomass content of this compartment is very small when compared to the other pools.

\section{ACKNOWLedgMents}

I would like to thank Ecosistemservices for funding the inventory activities and allowing us to use the information. I would like to thank Setambiental for providing data and supporting this paper.

\section{RESUMO}

No Brasil, uma redução significativa nas taxas de desmatamento ocorreu durante a última década. Apesar desse fato, as taxas médias anuais ainda estão muito altas, aproximadamente 400.000 ha/ano (INPE/Prodes). Os projetos de redução de emissões pelo desmatamento evitado (REDD+) são uma ferramenta importante para reduzir as taxas do desmatamento no Brasil. Entender a estrutura da floresta amazônica em termos de estoque de biomassa é chave para desenvolvimento de estratégias para reduzir desmatamento. Nesse estudo, analisamos resultados de dados da biomassa acima do solo de 1.019.346,27 hectares no estado do Pará. Foram coletados dados de 16.722 arvores em 83 parcelas sorteadas independentemente. Foram testadas 4 equações alométricas para DAP $>10 \mathrm{~cm}$ : Brown et al. (1989), Brown and Lugo (1999), Chambers et al. (2000), Higuchi et al. (1998). Foi revelado que o maior estoque de carbono da biomassa acima do solo está estocado no intervalo entre $30 \mathrm{~cm}$ e $80 \mathrm{~cm}$ DAP. Esse compartimento de biomassa estoca $75.70 \%$ da biomassa total na equação de Higuchi et al. (1998), 75.56\% da biomassa total na equação de Brown et al. (1989), 78.83\% do total de biomassa na equação de Chambers et al. (2000), e $73.22 \%$ na equação de Brown and Lugo (1999).

Palavras-chave: desmatamento na Amazônia, projetos REDD+, mudança climática, carbono florestal.

\section{REFERENCES}

ARaúJo TM, Higuchi N AND CARVAlho JR JA. 1999. Comparison. Forest Ecol Manag 117: 43-52.

BAKER TR ET AL. 2004. Variation in wood density. J Glob Chang Biol 10(5): 545-562.

BERENGUER E ET AL. 2014. A large-scale field assessment of carbon stocks. Glob Chang Biol 20(12): 3713-3726.

BROWN S, GILLESPIE A, GILLESPIE JR AND LUGO AE. 1989. Biomass Estimation Methods. Forest Sci 35(4): 881-902.

BROWN S AND LUGO AE. 1999. Aboveground estimates. Interciencia $17(1)$. 
Bruce WN, Mesquita R, Pereira JLG, Souza SGA, BATISTA GT AND COUTO LB. 1998. Allometric regressions for improved estimate. Forest Ecol Manag 117: 149-167.

CARDENAS RJD. 1988. Levantamento e análise da fitomassa. INPA, Manaus, Amazonas, Brasil, 277 p.

CHAMBERS JQ. 2000. In: Tree damage, allometric relationships. Joaquim dos Santos, Ralfh J. Ribeiro, Niro Higuchi (Eds), Forest Ecol Manag 5348: 1-12.

CHAVE J ET AL. 2005. Tree allometry and improved estimation. Oecologia 145: 87-99.

COSTA LGS, MiRANDA IS, GRIMALDI M, Silva ML, MitJA D AND LIMA TTS. 2012. "Biomass in different types". Forest Ecol Manag 278: 101-109.

DUTSCHKE M ET AL. 2008. http://unfccc.int/files/methods_ science/redd/application/pdf/financing_redd.pdf.

EULER MN. 2008. Densidade da madeira. INPA, PBTRN, CFJ, Manaus, Amazonas, Brasil, p. 62.

FEARNSIDE PM, YANAI AM AND VITEL CSMN. 2013. Modeling Baselines for REDD. In: Impacts of Carbon-Optimised Land Use Management in Southern Amazonia - Multidisciplinary Perspectives. Carbiocial, Universidade Federal de Mato Grosso (UFMT) \& FONA Research for Sustainable Development BMBF, Cuiabá, Mato Grosso, Chapter 2: 1-11.

GARDNER TA ET AL. 2013. A social and ecological assessment of tropical land uses at multiple scales: the Sustainable Amazon Network, The Royal Society.

GERWING J ET AL. 2002. Degradation of forests through logging. Forest Ecol Manag 157: 131-141.

GIBBS HK, OLANDER LP, STEININGER M, SWENSON J AND MURRAY BC. 2007a. Reference scenarios for deforestation. Environ Res Lett 3(2).
GibBS HK, BROWN S, NiLES JO AND FOLEY JA. $2007 \mathrm{~b}$. Monitoring and estimating tropical forest. Environ Res Lett 2(045023): 13 p.

HAYASHI S, SOUZA JR C, SALES M AND VERÍSSIMO RA. 2010. Boletim Transparência Florestal Amazônia Legal (Março de 2010), Belém: Imazon, 12 p.

Higuchi N, SANTOS J, RiBEIRO RJ, MiNETTE L AND BIOT Y. 1998. Biomassa da parte aérea. ACTA Amaz 28(2): 153 166.

IBGE - INSTITUTO BRASILEIRO DE GEOGRAFIA E ESTATÍSTICA. 2015. Indicadores conjunturais, relatório agosto 2015. (http://www.ibge.gov.br).

LAURANCE WF ET AL. 1999. Relationship between soils and Amazon forest biomass: a landscape-scale study. Forest Ecol Manag 118(1999): 127-138.

LEVINE JS. 1991. Global Biomass Burning, MIT press, Cambridge, Mass: p. 569.

NASSAR A ET AL. 2010. Everything is connected. Brasil: Defra, British Embassy Brasília: 29-31.

NogueIRA EM. 2008. Densidade da madeira. Instituto Nacional de Pesquisas da Amazônia - INPA. Programa de pós-graduação em ciências de florestas tropicais - CFT, Tese Doutorado, $151 \mathrm{p}$.

PERMAN R, Yue MAM, MCGILVRAY J AND COMMON M. 2003. Nat Resour Environ Econ, $3^{\text {rd }}$ ed., p. 218.

Tennigkeit T, Held C, CARodenuto S AND Merger E. 2013. Financing REDD+. Freiburg, Germany.

VIEIRA S ET AL. 2004. Forest structure and carbon. Oecologia 140: 468-479. 